\title{
Optimasi Kendali PID menggunakan Algoritma Genetika untuk Penerbangan Quadrotor
}

\author{
Khalaqas Hakiim*1, Andi Dharmawan ${ }^{2}$ Faizah $^{3}$ \\ ${ }^{1}$ Prodi S1 Elektronika dan Instrumentasi, FMIPA UGM, Yogyakarta \\ ${ }^{2,3}$ Departemen Ilmu Komputer dan Elektronika, FMIPA UGM, Yogyakarta \\ e-mail: *11 khalaqashakiim@gmail.com, ${ }^{2}$ dharmawan.andi@gmail.com,${ }^{3}$ faizah@ugm.ac.id
}

\begin{abstract}
Abstrak
Quadrotor merupakan jenis pesawat tanpa awak (UAV) berbentuk persegi dengan empat motor ditiap lengannya. Quadrotor memiliki kemampuan untuk terbang landas dan mendarat secara vertikal. Pada penelitian ini dirancang dan dibuat sistem yang mampu menstabilkan terbang quadrotor serta mampu mempertahankan sudut roll, pitch, yaw menggunakan kendali PID yang dioptimasi menggunakan salah satu evolutionary algorithms yaitu algoritma genetika.

PID merupakan kendali yang umum diterapkan termasuk untuk mengendalikan quadrotor. Penalaan atau proses pengaturan parameter PID sangat dibutuhkan untuk mendapatkan parameter PID yang tepat sehingga tercapai kestabilan terbang. Pada penelitian ini diterapkan penalaan Ziegler-Nichols dalam mencari parameter PID yang selanjutnya dijadikan acuan optimasi algoritma genetika untuk mendapatkan parameter PID yang paling cocok pada pengendalian sudut roll, pitch, dan yaw.

Hasil optimasi yang telah dilakukan menunjukkan kendali quadrotor mampu menghasilkan kestabilan dengan steady state error untuk sudut pitch yaitu 2,34 derajat conterclockwise hingga 3,37 derajat clockwise, pada sudut roll yaitu 2,99 derajat counterclocwise hingga 2,27 derajat clockwise, dan pada sudut yaw yaitu 8,39 derajat counterclockwise hingga 3,89 derajat clockwise.
\end{abstract}

Kata kunci-UAV, Evolutionary Algorithms, Ziegler Nichols

\begin{abstract}
Quadrotor is square-form unmanned aerial vehicle (UAV) type with four motor in each arms. Quadrotor has ability to take-off and landing vertically. This research designs and creates a system that capable to stabilize the quadrotor flight also able to maintain roll, pitch and yaw angle using PID controller optimized by genetic algorithm, one of evolutionary
\end{abstract} algorithms.

PID is a common applied controller including to control the quadrotor. Tunning or setting PID parameter process is needed to obtain fit PID parameters. Tunning is very important to reach quadrotor flight stability. This research applies Ziegler-Nichols tunning to obtain PID parameters. Then the PID parameters will be a reference for genetic algorithm optimization process to obtain the suitest PID parameter to control roll, pitch, and yaw angle.

Optimization process result show quadrotor controller capable to reach stability with steady state error for pitch angle in range 2,34 degree conterclockwise to 3,37 degree clockwise, for roll angle in range 2,99 degreee counterclockwise to 2,27 degree clockwise, and for yaw angle in range 8,39 degree counterclockwise to 3,89 degree clockwise.

Keywords-UAV, Evolutionary Algorithms, Ziegler Nichols 


\section{PENDAHULUAN}

$\mathrm{B}$ eberapa tahun belakangan ini salah satu teknologi yang pesat pemanfaatannya dan perkembangannya adalah quadrotor. Quadrotor telah banyak diaplikasikan dalam berbagai bidang diantaranya dalam jurnalistik, pemantauan dan pengawasan suatu wilayah, pemetaan wilayah, pemantauan lalu lintas hingga misi penyelamatan. Quadrotor merupakan bagian dari pesawat tanpa awak yang bergerak terbang dengan menggunakan daya dorong yang dihasilkan keempat motornya [1]. Quadrotor merupakan UAV yang memiliki kemampuan vertical take-off and landing (VTOL) dan kemampuan manuver yang tinggi [2].

Quadrotor dapat diterbangkan secara manual oleh pilot menggunakan remote, akan tetapi seringkali quadrotor mengalami ketidakstabilan dalam terbang. Selain itu seringkali quadrotor diberikan muatan untuk mendukung peformanya sehingga sangat diperlukan sistem kendali yang mumpuni untuk menjaga kestabilan terbangnya [3].

Faktor baiknya peforma yang dihasilkan dan kemudahan dalam pengimplementasiannya menjadikan kendali PID cocok untuk diterapkan untuk pengendalian quadrotor. Pengendalian pada quadrotor dengan menggunakan kendali PID tanpa pengaturan parameter-parameter PID secara tepat terhadap dinamika gerakan quadrotor yang seringkali berubah-rubah dapat mengakibatkan overshoot yang tinggi sehingga terjadi perlambatan respon sistem dan multiple overshoot. Pengendalian quadrotor dengan kendali PID disertai pengaturan parameterparameternya secara tepat akan berimbas pada terbang quadrotor yang stabil dan dapat mempertahankan posisi quadrotor pada sudut eulernya. Solusi untuk mendapatkan nilai parameter PID secara tepat adalah dengan melakukan penalaan atau tunning. Sistem pada quadrotor adalah sistem nonlinear karena aerodinamika dari keempat rotor yang membutuhkan sebuah algoritma kendali untuk menstabilkan pada saat keadaan melayang [4].

Algoritma Genetika merupakan algoritma yang bekerja didasarkan pada prinsip evolusi alami dan genetika dalam pencarian solusi dalam sebuah permasalahan [5]. Algortima genetika adalah proses pencarian suatu kromosom (solusi) yang paling cocok yang dibangun populasi pada lingkupan solusi yang potensial. Algoritma genetika terkenal sebagai algortima dengan metode penncarian yang acak yang dapat menghasilkan solusi optimal yang akurat. Kemampuan untuk melakukan pencarian solusi yang optimal tersebut sangat memungkinkan untuk diterapkan dalam rangka menala parameter PID.

\section{METODE PENELITIAN}

\subsection{Analisis Sistem}

Quadrotor merupakan model pesawat yang memiliki empat baling-baling yang terpasang pada lengan secara simetris. Hal ini memungkinkan quadrotor untuk melakukan lepas landas dan pendaratan secara vertikal. Putaran motor quadrotor adalah searah jarum jam atau clockwise $(\mathrm{CW})$ dan berlawanan awah jarum jam atau conuterclockwise $(\mathrm{CCW})$. Arah dua motor yang bersebelahan memiliki arah putaran yang berbeda, sehingga memungkinkan quadrotor untuk dapat terbang. Pada penelitian ini konfigurasi quadrotor berbentuk ' $\mathrm{X}$ ' dan arah perputaran motor sesuai Gambar 1. 


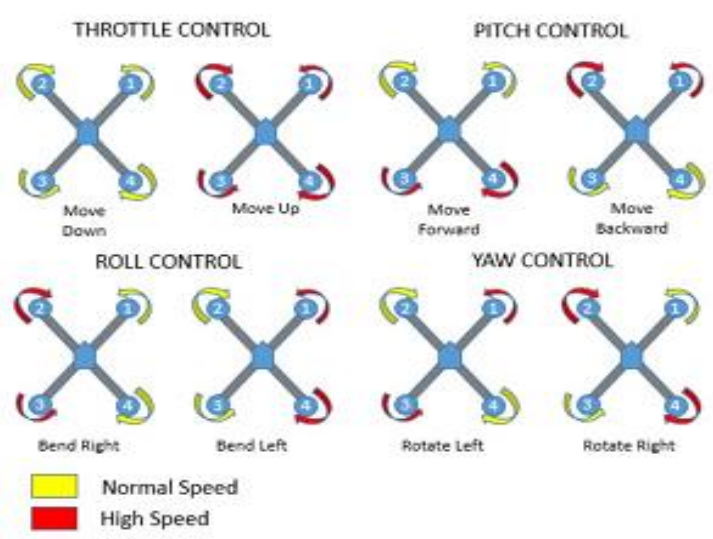

Gambar 1 Pergerakan dasar quadrotor [6]

Penelitian mengenai quadrotor ini bertujuan untuk mengendalikan quadrotor. Pengendalian quadrotor dipengaruhi beberapa parameter yaitu throttle, pitch, roll, dan yaw. Throttle berpengaruh pada pengaturan kecepatan motor yang menyebabkan naik turunnya quadrotor. Pitch dan Roll berpengaruh pada sudut kemiringan quadrotor. Sedangkan yaw berpengaruh pada arah hadap quadrotor. Sistem kendali quadrotor menggunakan PID( Proportional Integral Derivative). Sistem kendali ini merupakan sistem yang linear, persamaan PID yang digunakan adalah persamaan 1 .

$\mathrm{u}(\mathrm{t})=\mathrm{Kp} e(t)+K i \int_{0}^{t} e(t) d t+K d \frac{d e(t)}{d t}$

Batasan toleransi untuk nilai steady state error pada sistem close-loop yang linear(orde 1) adalah sebesar $2 \%$ dari rentang nilai yang digunakan [7]. Sedangkan pada penelitian ini yang digunakan merupakan sistem non-linier yang berorde dua. Tidak terdapat aturan yang pasti untuk nilai toleransi pada sistem non-linier, pada penelitian ini digunakan toleransi steady state error adalah maksimal sebesar 5\% dari rentang nilai yang digunakan.

Nilai $5 \%$ merupakan nilai toleransi dan beberapa parameter lain yang digunakan sebagai acuan keberhasilan dari sistem kendali dalam menangani quadrotor disebutkan dalam penelitian sebelumnya [8] :

1. Nilai steady state error dibawah batas toleransi $5 \%$ dari nilai maksimal yaitu sebesar 90 derajat untuk sudut pitch dan roll yang dapat masih dikendalikan dan sudut 360 derajat untuk sudut yaw sehingga batas toleransi sudut adalah 4,5 derajat clockwise $(\mathrm{CW})$ dan 4,5 derajat countercolwise $(\mathrm{CCW})$ untuk sudut pitch dan roll, serta sebesar 18 derajat clockwise $(\mathrm{CW})$ dan 18 derajat countercolwise $(\mathrm{CCW})$ pada sudut yaw.

2. Rise time yang dihasilkan untuk sudut pitch dan roll lebih cepat dari satu detik dan untuk yaw lebih cepat dari 4 detik.

3. Settling time yang dihasilkan untuk sudut pitch dan roll lebih cepat dari 3 detik dan untuk sudut yaw lebih cepat dari 6 detik.

Maximum overshoot untuk sudut pitch dan roll yang dihasilkan lebih kecil dari $20 \%$ dan untuk sudut yaw yang dihasilkan lebih kecil dari $20 \%$.

\subsection{Rancangan Arsitektur Quadrotor}

Penelitian tugas akhir ini terdapat beberapa komponen utama yang digunakan yaitu Arduino Due sebagai prosesor untuk program kendali yang digunakan. Sensor IMU 9 DOF yang terdiri dari 3 DOF accelerometer dan 3 DOF gyroscope dari sensor MPU6050 serta 3 DOF magnetometer dari sensor HMC5883L. Empat motor brushless sebagai aktuator utama pada quadrotor. Empat Electronic Speed Controller (ESC) sebagai pengatur kecepatan sudut dari motor brushless. Modul Radio Frequency(RF) $433 \mathrm{MHz}$ yang berfungsi dalam komunikasi 
nirkabel antara quadrotor dengan ground segment. Arsitektur sistem dari quadrotor yang digunakan ditampilkan dalam Gambar 2.

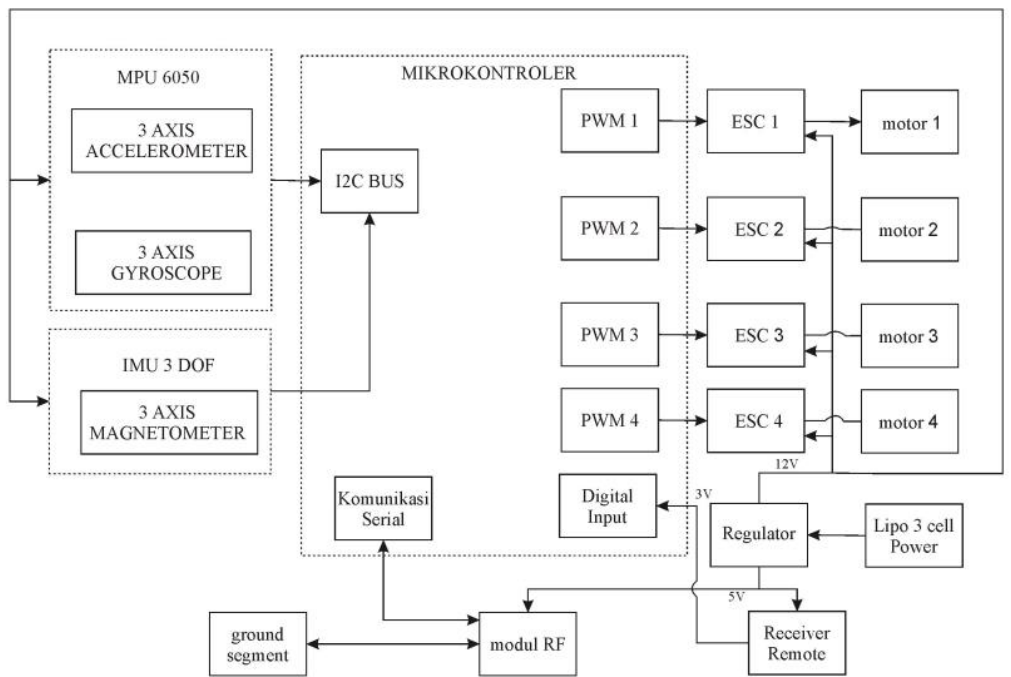

Gambar 2 Arsitektur sistem elektronis

\subsection{Fungsi Alih Quadrotor}

Fungsi alih quadrotor merupakan komponen yang penting dalam proses penstabilan quadrotor. Fungsi alih berperan penting yaitu mewakili keseluruhan sistem hardware quadrotor untuk diolah pada perangkat lunak yang diterapkan untuk quadrotor sehingga sangat menentukan kestabilan yang akan tercapai.

Dari persamaan permodelan, fungsi alih dalam domain laplace untuk sumbu $\mathrm{x}$ dikemukan persamaan 2.

$G_{x}(\mathrm{~s})=\frac{\frac{1}{2} \sqrt{2} 1}{I_{x x} S^{2}}$ sumbu.

Fungsi alih untuk sumbu y dan z persamaan 2 disesuaikan inersia pada masing-masing

\subsection{Tahap Rancangan dan pembuatan sistem kendali}

Pembuatan sistem kendali dalam penelitian ini terdiri dari beberapa tahapan sesuai dengan Gambar 3.

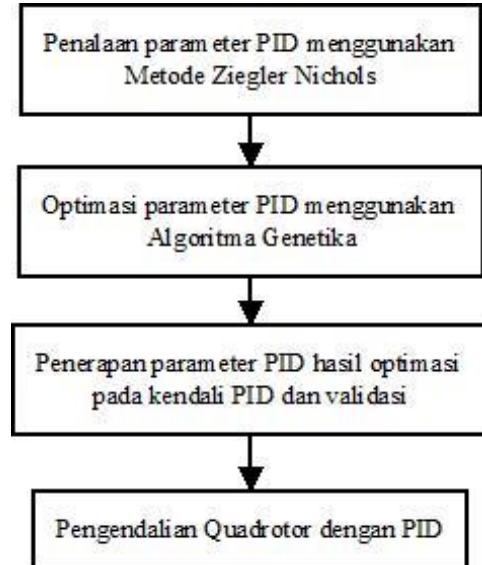

Gambar 3 Tahapan perancangan dan pembuatan sistem kendali 
Tahapan perancangan dan pembuatan sistem sesuai dengan Gambar 3 pada tahap awal terlebih dulu dilakukan penalaan paremeter PID dengan menggunakan metode Ziegler-Nichols. Metode Ziegler-Nichols dapat digunakan untuk memprediksi peforma sistem secara lebih akurat.

Metode Ziegler-Nichols dapat diaplikasikan pada plant yang diketahui permodelan matematikanya maupun yang tidak diketahui permodelan matematikanya. Meskipun dalam beberapa kasus hasilnya akan menimbulkan overshoot yang besar atau bahkan tidak cocok untuk diaplikasikan sehingga membutuhkan fine tuning. Akan tetapi metode ini dapat dijadikan acuan standar sebagai permulaan dalam mencari nilai parameter terbaik [8].

Proses optimasi algoritma genetika akan menghasilkan parameter yang teroptimasi sehingga kemudian akan dilakukan penerapan pada kendali PID, akantetapi apabila dirasa perlu dapat dilakukan validasi parameter pada kendali quadrotor. Pada tahap terakhir, PID yang telah berisi parameter yang telah teroptimasi akan digunakan sebagai pengendali pada quadrotor.

\subsection{Rancangan Sistem Kendali Quadrotor}

Rancangan sistem kendali dibuat untuk dijadikan acuan dalam pembuatan sistem kendali untuk kestabilan terbang quadrotor. Rancangan kendali ini berupa blok yang ditampilkan pada Gambar 4.

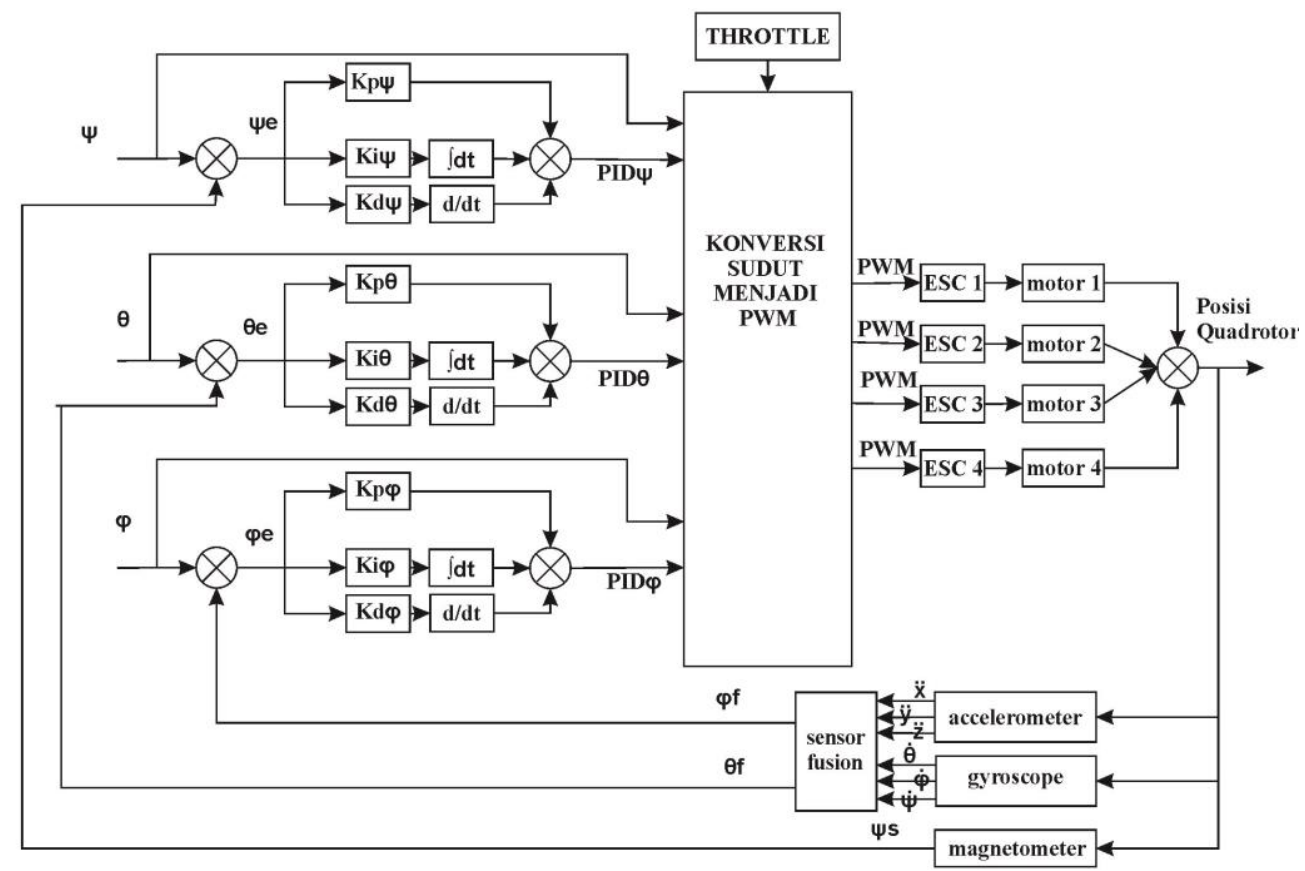

Gambar 4 Diagram blok kendali sistem

Sistem kendali diawali dengan proses pencarian nilai error dari hasil selisih setpoint dengan feedback pembacaan sudut dari sensor. Pembacaan sudut pada keluaran sistem diolah dengan metode DMP. Setpoint pitch, roll, dan yaw diwakilkan dengan simbol $\theta, \varphi, \psi$. Nilai error kemudian akan diproses oleh kendali PID yang sebelumnya parameter-parameternya sudah dioptimasi dengan menggunakan algoritma genetika. Nilai PID yang dihasilkan akan dilakukan konversi niali PID ke PWM. Motor brusless akan berputar pada kecepatan sudut tertentu yang bertujuan untuk memposisikan quadrotor pada posisi tertentu. Posisi quadrotor akan dibaca dengan menggunakan 3 sensor untuk mendapatkan nilai sudut feedback $\theta_{f}, \phi_{f}, \psi_{s}$. 


\subsection{Optimasi Algoritma Genetika}

Optimasi parameter kendali PID menggunakan metode algortima genetika merupakan proses peningkatan optimalisasi parameter yang sudah ditala dengan menggunakan metode Ziegler-Nichols. Proses optimasi algoritma genetika akan mengacu pada parameter-parameter yang sudah didapatkan melalui proses Ziegler-Nichols.

Program optimasi parameter kendali PID menggunakan algoritma genetika diawali dengan deklarasi dan penginisialisasian variabel yang digunakan dalam prosesnya. Kemudian proses selanjutnya adalah fungsi pembangkitan nilai parameter awal secara acak akan tetapi tetap pada nilai acuan disekitar nilai parameter hasil penalaan menggunakan metode ZieglerNichols. Gambar 5 menunjukkan bagan alir optimasi algoritma genetika.

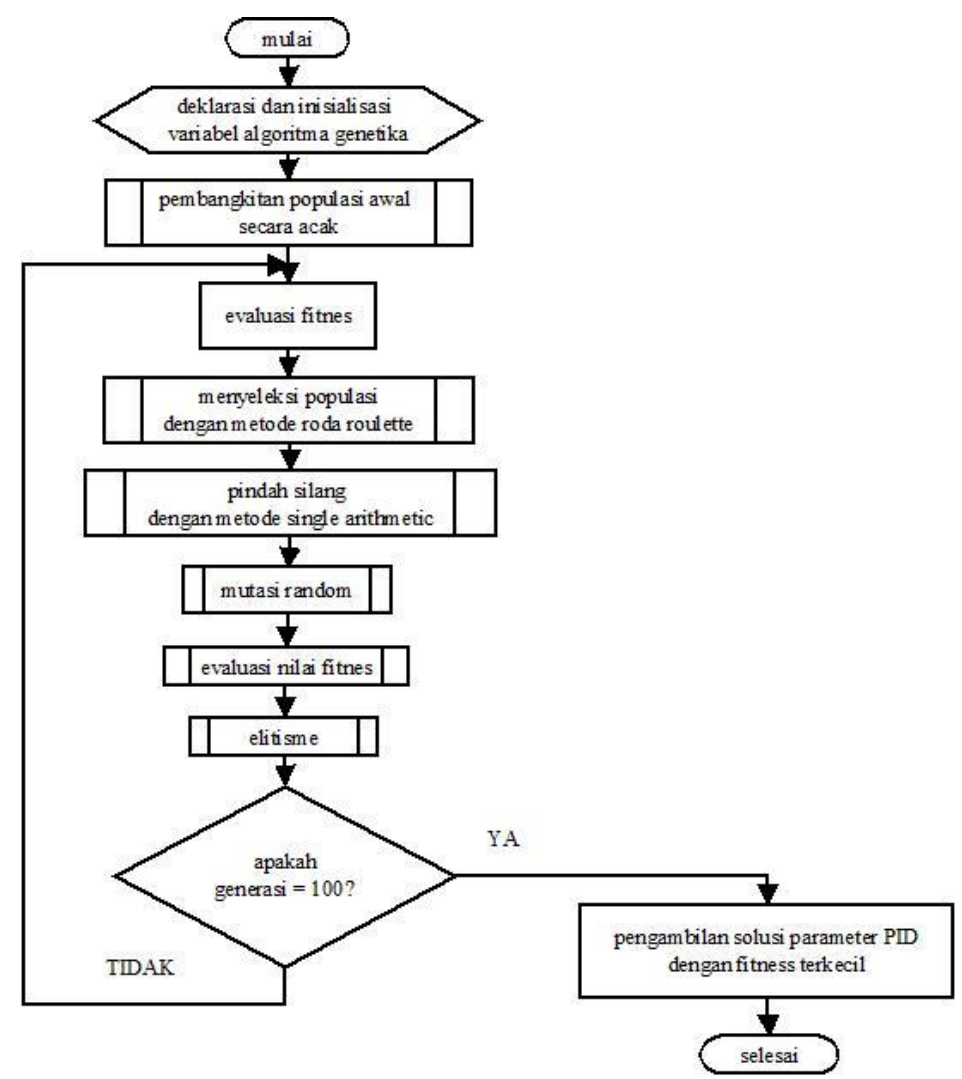

Gambar 5 Bagan alir optimasi algoritma genetika

Tahapan selanjutnya adalah seleksi populasi, populasi akan dilakukan penyeleksian pada tahap fungsi seleksi menggunakan metode roda roulette. Populasi hasil seleksi roda roulette akan dilanjutkan untuk diproses pada fungsi pindah silang. Dalam proses pindah silang digunakan metode single arithmatic yang akan melakukan penukaran pada gen-gen tertentu dalam populasi. Tahapan selanjutnya adalah pada fungsi mutasi yang akan melakukan mutasi terhadap gen-gen terpilih. Dalam penelitian ini dipilih nilai peluang mutasi yang rendah karena nilai peluang mutasi yang tinggi akan mengakibatkan proses pencarian optimasi menjadi suatu pencarian yang acak [9].

Hasil dari proses mutasi akan kembali dievaluasi menggunakan ITAE. Pada dasarnya cost function IAE, ISE, ITAE, maupun ITSE memiliki hasil respon peforma yang hampir sama baiknya, akan tetapi ITAE memiliki indeks peforma yang lebih baik daripada ketiga cost function lainnya [11]. 
Elitisme ini akan mempertahankan kualitas populasi untuk dapat digunakan sebagai orangtua pada genrasi selanjutnya. Proses pembentukan generasi baru dengan operasi gentika dilakukan berulang-ulang hingga terpenuhi kriteria pemberhentian(stoping condition). Pada penelitian ini akan berlangsung selama 100 generasi, sehingga pada akhir generasi akan dapat diambil solusi terbaik yang diberikan dalam proses optimasi. Penelitian ini juga melakukan pengamatan terhadap parameter algoritma genetika seperti peluang mutasi, jumlah populasi dan jumlah generasi untuk menentukan seberapa konvergen hasil optimsinya.

\subsection{Pengambilan Data Parameter Model}

Perangkat keras yang digunakan akan dillakukan pengukuran massa maupun panjang yang akan digunakan untuk mendapatkan nilai. Pengukuran ini dilakukan pada sumbu-sumbu inersia tiap komponen berdasarkan pada bentuknya masing-masing. Nilai hasil pengukuran akan digunakan untuk mencari inersia tiap-tiap komponen perangkat keras. Nilai tersebut digunakan untuk mendapatkan nilai fungsi alih pada sistem quadrotor.

Nilai inersia total pada sumbu $\mathrm{x}$ adalah 0,03715163 ,dan inersia total pada sumbu y adalah 0,03895026 serta nilai total inersia pada sumbu $\mathrm{z}$ adalah 0,2276909 . Nilai inersia total pada sumbu $\mathrm{x}, \mathrm{y}$,dan $\mathrm{z}$ akan digunakan pada persamaan fungsi alih. Fungsi alih ini akan digunakan dalam penyusunan program optimasi menggunakan algoritma genetika.

\section{HASIL DAN PEMBAHASAN}

\subsection{Optimasi ParameterPID pada sudut roll}

Optimasi parameter PID dengan algoritma genetika pada sudut roll mengacu pada nilai parameter yang telah ditala menggunakan metode Ziegler-Nichols. Gambar 6 merupakan grafik salah satu solusi optimasi untuk parameter PID pada sudut roll yang disediakan oleh algoritma genetika.

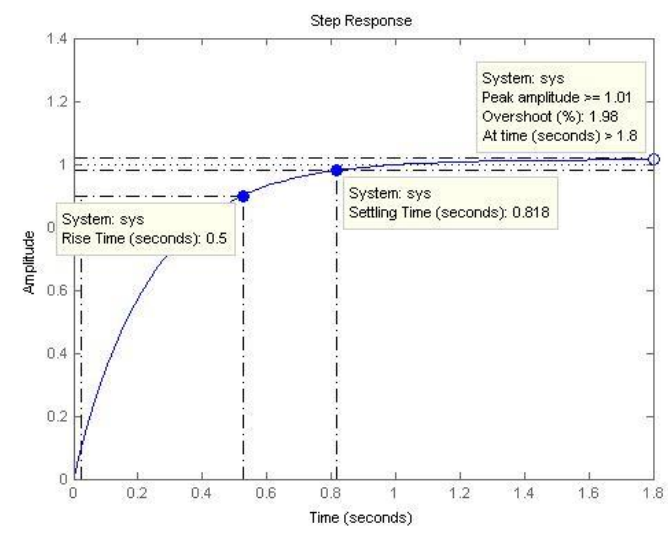

Gambar 6 Grafik respon sistem optimasi parameter PID pada sudut roll dengan algoritma genetika

Dari simulasi optimasi parameter kendali PID sudut roll menggunakan algortima genetika didapat risetime 0.5 detik, overshoot $1,98 \%$, serta settlingtime 0,818 detik. Berdasarkan kriteria kestabilan yang ditentukan, respon sistem yang dihasilkan dari simulasi dianalisa bahwa respon sistemnya memenuhi spesifikasi yang ditentukan dalam penelitian ini yaitu risetime yang didapatkan lebih cepat dari 1 detik, overshootnya kurang dari $20 \%$ dan settlingtime nya lebih cepat dari 3 detik. Solusi parameter yang diberikan dari hasil simulasi tersebut yaitu $\mathrm{Kp}=0,514 \mathrm{Ki}=0,0102$ dan $\mathrm{Kd}=0,9887$ dan fitnes $=2,6484$.

\subsection{Optimasi ParameterPID pada sudut roll}

Optimasi parameter PID dengan algoritma genetika pada sudut pitch mengacu pada nilai parameter yang telah ditala menggunakan metode Ziegler-Nichols.Gambar 7 merupakan 
grafik salah satu solusi optimasi untuk parameter PID pada sudut pitch yang disediakan oleh algoritma genetika.

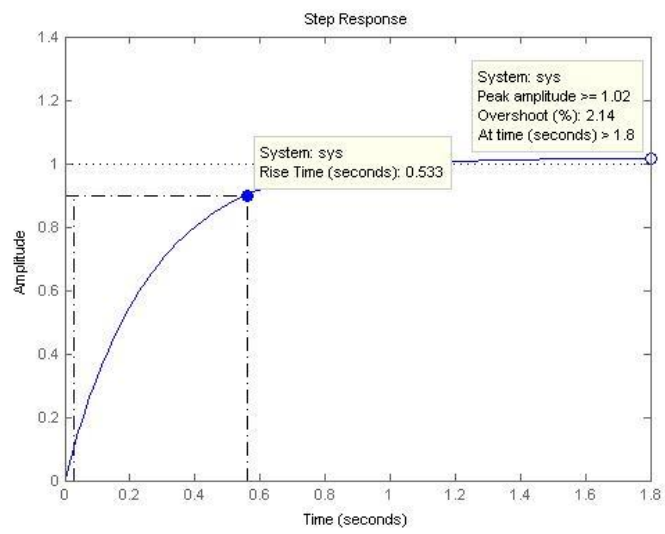

Gambar 7 grafik respon sistem optimasi parameter PID pada sudut pitch dengan algoritma genetika

Grafik optimasi parameter PID sudut pitch pada Gambar 7 menunjukkan respon sistem dengan risetime 0,533 detik, overshoot sebesar $2,14 \%$ dan settlingtime sangat singkat. Berdasarkan kriteria kestabilan yang ditentukan, respon sistem Gambar 7 apabila dianalisa sudah memasuki spesifikasi yang ditentukan pada penelitian ini yaitu lebih cepat dari 1 detik untuk risetime, overshoot kurang dari $20 \%$ dan settlingtime lebih cepat dari 3 detik. Solusi parameter yang dihasilkan dalam optimasi parameter PID dengan menggunakan algoritma genetika untuk sudut pitch ini adalah $\mathrm{Kp}=0,0555 \mathrm{Ki}=0,0101$ dan $\mathrm{Kd}=0,9671$ dan fitnes = 3,3608 .

\subsection{Optimasi ParameterPID pada sudut yaw}

Optimasi parameter PID dengan algoritma genetika pada sudut yaw mengacu pada nilai parameter yang telah ditala menggunakan metode Ziegler-Nichols. Gambar 8 merupakan grafik salah satu solusi optimasi untuk parameter PID pada sudut yaw yang disediakan oleh algoritma genetika.

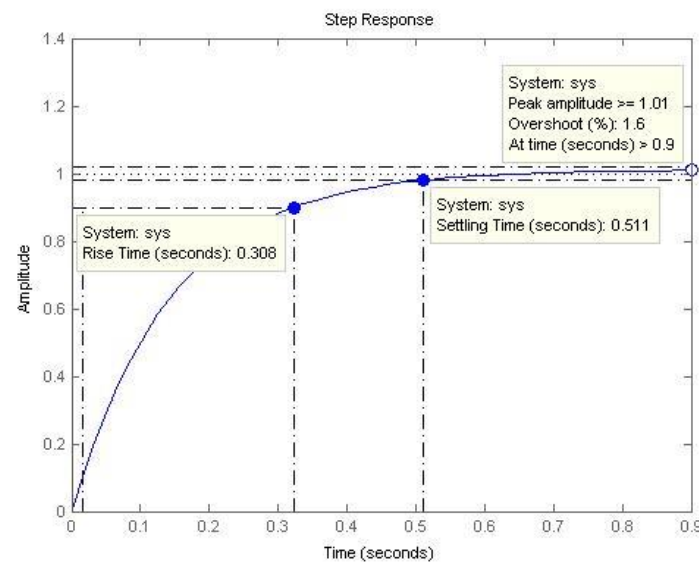

Gambar 8 grafik respon sistem optimasi parameter PID pada sudut yaw dengan algoritma genetika

Grafik hasil optimasi parameter PID sudut yaw dengan menggunakan algortima genetika pada Gambar 8 menunjukkan respon sistem risetime 0.31 detik , overshoot sebesar 1,6 $\%$ dan settlingtime 0,516 detik. Berdasarkan kriteria kestabilan yang ditentukan, respon sistem yang demikian apabila dianalisa menunjukkan bahwa respon sistem tersebut sudah masuk ke 
dalam spesifikasi yang ditentukan dalam penelitian. Pemenuhan spesifikasi dibuktikan dengan risetime yang dihasilkan lebih cepat dari 1 detik, settlingtime lebih cepat dari 3 detik dan overshoot kurang dari $20 \%$. Solusi parameter yang dihasilkan dalam optimasi parameter PID menggunakan algortima gentika yaitu $\mathrm{Kp}=0,0688 \mathrm{Ki}=0,0179$ dan $\mathrm{Kd}=0,9906$ dan fitnes $=$ 1,2138 .

\subsection{Respon Hasil Metode Algoritma Genetika}

Hasil respon sistem pada quadrotor dengan optimasi parameter PID mengunakan algortima genetika pada sudut roll menghasilkan risetime 0,75, overshoot sebesar $9 \%$, serta settlingtime 2,85 detik. Berdasarkan ketetntuan kriteria kestabilan quadrotor dapat dianaliasa bahwa risetime yang dihasilkan sudah memenuhi kriteria yang diinginkan yaitu lebih cepat dari 1 detik, demikian juga pada overshoot yang besar maksimal harus kurang dari $20 \%$ dan settlingtime lebih cepat dari 3 detik. Steady state error yang pada grafik menunjukkan berada pada rentang 3,13 derajat counterclocwise hingga 3,1 derajat clockwise. Rentang error yang dihasilkan pada optimasi dengan algoritma genetika memenuhi steady state error kebutuhan sistem yang diinginkan yaitu $5 \%$ dari nilai yang dikendalikan.

Hasil respon sistem pada quadrotor dengan optimasi parameter PID menggunakan algortima genetika pada sudut pitch menghasilkan risetime 0,8 , overshoot sebesar $9 \%$, serta settlingtime 2,85 detik. Mengacu pada batas kritetia kestabilan, risetime yang dihasilkan sudah memenuhi kriteria yang diinginkan yaitu lebih cepat dari 1 detik, demikian juga pada overshoot yang besar maksimal harus kurang dari $20 \%$ dan settlingtime lebih cepat dari 3 detik. Steady state error yang pada grafik menunjukkan berada pada rentang 3,13 derajat counterclockwise hingga 3,1 derajat clockwise. Rentang error yang dihasilkan pada optimasi dengan algoritma genetika memenuhi steady state error kebutuhan sistem yang diinginkan yaitu $5 \%$ dari nilai yang dikendalikan.

Hasil respon sistem pada quadrotor dengan optimasi parameter PID menggunakan algortima genetika pada sudut yaw menghasilkan risetime 1,05, overshoot maksimum sebesar $19,18 \%$, serta settlingtime 4,3 detik. Mengacu pada kriteria kestabilan, dapat dianalisa bahwa risetime yang dihasilkan sudah memenuhi kriteria yang diinginkan yaitu lebih cepat dari 4 detik, demikian juga pada overshoot yang besar maksimal harus kurang dari $20 \%$ dan settlingtime lebih cepat dari 6 detik. Steady state error yang pada grafik menunjukkan berada pada rentang 9,02 derajat counterclockwise hingga 6,58 derajat clockwise. Rentang error yang dihasilkan pada optimasi dengan algoritma genetika memenuhi steady state error kebutuhan sistem yang diinginkan yaitu pada rentang 18 derajat counterclockwise hingga 18 derajat clockwise.

\subsection{Uji Terbang Quadrotor}

Uji terbang quadrotor dilakukan dengan cara menerbangkan quadrotor pada lingkungan terbuka untuk diamati respon sistem yang dihasilkan. Pada uji terbang ini parameter yang dihasilkan pada optimasi PID dengan algoritma genetika dan telah divalidasi, diterapkan pada sistem quadrotor. Gambar 9 adalah grafik sudut terbang pada pitch, roll, serta yaw dalam 10 detik.

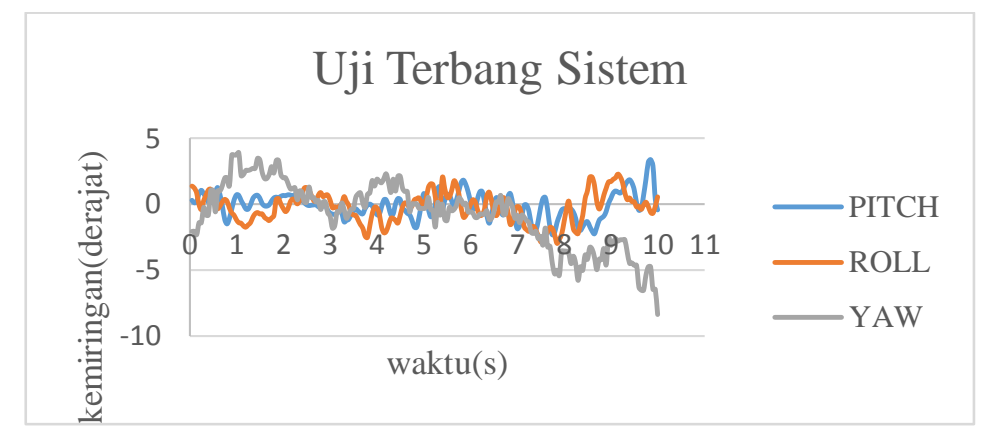

Gambar 9 Grafik hasil uji terbang 
Respon sistem pada sudut roll saat terbang menghasilkan sudut simpangan terbesar pada sudut kemiringan 2,99 derajat counterclockwise. Sudut tersebut merupakan simpangan yang normal karena memenuhi kriteria kestabilan dalam penelitain, selain itu penerbangan quadrotor dilakukan di ruang terbuka sehingga bisa dimungkinkan terjadi ketidakstabilan karena faktor luar. Steady state error respon sistem pada sudut roll yang dihasilkan berada pada rentang 2,99 derajat counterclockwise hingga 2,27 derajat clockwise. Berdasarkan kriteria spesifikasi respon sistem yang ditentukan dalam penelitian, maka steady state error yang dihasilkan dalam pengendalian quadrotor sudah memenuhi.

Respon sistem pada sudut pitch saat uji terbang menghasilkan simpangan kemiringan terbesar pada sudut 3,37 derajat clockwise. Sudut tersebut merupakan simpangan yang normal karena memenuhi kriteria kestabilan dalam peneilitan dan juga penerbangan dilakukan di ruang terbuka dengan kondisi yang dimungkinkan terkena maupun faktor luar sehingga terjadi ketidakstabilan. Steady state error respon sistem pada sudut pitch yang dihasilkan berada pada rentang 2,34 derajat counterclockwise hingga 3,37 derajat clockwise. Berdasarkan kriteria spesifikasi respon sistem yang diinginkan, steady state error yang dihasilkan sudah memenuhi yaitu seperti pada spesifikasi sudut roll berada pada rentang simpangan 4,5 derajat counterclockwise hingga 4,5 derajat clockwise.

Respon sistem pada sudut yaw saat uji terbang menghasilkan sudut simpangan terbesar pada sudut 8,39 derajat counterclockwise. Sudut tersebut merupakan simpangan yang normal karena sudah memenuhi kriteria yang ditentukan dalam penelitian, selain itu juga penerbangan dilakukan pada ruang terbuka sehngga dimungkinkan terjadi gangguan kestabilan karena faktor luar. Steady state error sistem pada sudut yaw yang dihasilkan berada pada rentang 8,39 derajat counterclockwise hingga 3,89 derajat clockwise. Berdasarkan kriteria spesifikasi respon sistem yang ditentukan dalam penelitian, steady state error pada respon sistem sudut yaw sudah memenuhi dengan rentang minimal 18 derajat counterclockwise hingga maksimal 18 derajat clockwise.

\section{KESIMPULAN}

Berdasarkan penelitian yang telah dilakukan, kesimpulan yang bisa diambil adalah telah berhasil dirancang dan diimplementasikan metode optimasi parameter PID berdasarkan algoritma genetika pada kendali quadrotor untuk mencapai kestabilan quadrotor pada sudut roll, pitch, dan yaw dengan rincian sebagai berikut:

1. Pengujian perbandingan parameter algoritma genetika menunjukkan bahwa variasi parameter mempengaruhi tingkat konvergen hasil optimasi. Tingkat konvergen hasil optimasi terbaik ditunjukkan pada variasi parameter jumlah generasi sebesar 100 dan 150 , jumlah individu dalam satu populasi sebesar 10 dan 20, serta besar peluang mutasi sebesar 0,1 .

2. Hasil pengujian kendali PID dengan penalaan Ziegler Nichols menggunakan simuasi MATLAB pada sudut pitch, roll maupun yaw menunjukkan bahwa respon sistem yang dihasilkan belum memenuhi kriteria kestabilan yang ditentukan dalam penelitian sehingga belum cocok diterapkan pada quadrotor untuk pengendalian kestabilan terbang.

3. Hasil pengujian kendali PID yang telah dioptimasi dengan algoritma genetika menggunakan simulasi MATLAB pada sudut pitch, roll, dan yaw menunjukkan bahwa respon sistem yang dihasilkan sudah memenuhi kriteria kestabila yang ditentukan dalam penelitian ini sehingga dianggap cocok diterapkan pada quadrotor untuk pengendalian kestabilan terbang.

4. Hasil pengujian kendali PID dengan optimasi algoritma genetika pada sudut roll, pitch, yaw, quadrotor menunjukkan respon sistem dihasilkan tersebut sudah memenuhi kriteria kestabilan pada sudut yaw yang ditentukan dalam penelitian.

5. Uji terbang quadrotor menunjukkan steady state error pada sudut roll yaitu pada rentang 2,99 derajat counterclocwise hingga 2,27 derajat clockwise, pada sudut pitch

IJEIS Vol. 7, No. 2, October $2017: 173-184$ 
yaitu pada rentang 2,34 derajat counterclockwise hingga 3,37 derajat clockwise, pada sudut yaw yaitu pada rentang 8,39 derajat counterclocwise hingga 3,89 derajat clocwise. Steady state error tersebut memenuhi kriteria kestabilan quadrotor yang ditentukan dalam penelitan.

\section{SARAN}

Penelitian ini masih terdapat beberapa hal yang perlu disempurnakan. Berikut saran yang dikemukakan untuk penelitian selanjutnya yang berhubungan dengan penelitian ini :

1. Diperlukan peningkatan penelitian dan penelitian lebih mendalam untuk merancang dan membuat sistem kendali berdasarkan metode optimasi genetika secara online

2. Penambahan kendali ketinggian dan posisi quadrotor agar quadrotor dapat terbang lebih stabil.

\section{UCAPAN TERIMA KASIH}

Penulis mengucapkan terima kasih kepada seluruh keluarga E-drones yang telah mendukung dan membantu dalam penelitian ini.

\section{DAFTAR PUSTAKA}

[1] A. Dharmawan, Y. Y. Simanungkalit, and N. Y. Megawati, "Pemodelan Sistem Kendali PIDpada Quadcopterdengan Metode Euler Lagrange," IJEIS (Indonesian J. Electron. Instrum. Syst., vol. 4, no. 1, pp. 13-24, Apr. 2014 [Online]. Available: https://jurnal.ugm.ac.id/ijeis/article/view/4218. [Accessed: 31-Oct-2017]

[2] Lee, K., Kim, H., Park, J. B. dan Choi, Y. H.,2012, Hovering Control of a Quadrotor. International Conference on Control, Automation, and Systems.

[3] Ashari, A., Lelono, D., Usuman, I., Dharmawan A., dan Supardi,T., 2012, Sistem Kendali dan Muatan Quadcopter Sebagai Sistem Pendukung Evakuasi Bencana, Prosiding InSINas;

[4] Raharja, Iswanto, N., Wahyunggoro, O., dan Cahyadi, A., 2015, Altitude Control for Quadrotor with Mamdani Fuzzy Model, Institute of Electrical and Electronics Engineers Journal.

[5] Singh, R., and Sen, I., 2004, Tuning OF PID Controller based AGC System Using Genetic Algorithms, Institute of Electrical and Electronics Engineers Journal.

[6] Navajas, G. T. and Prada, S. R., 2014, Buiding Your Own Quadrotor : A Mechatronics System Design Case Study, Institute of Electrical and Electronics Engineers Journal.

[7] Ogata, K. , 2002, Modern Control Engineering.

[8] Dharmawan, A and Rahani, F. F., 2016, Penalaan Mandiri Komponen PID dengan Metode JST pada Sistem Kendali Quadrotor,Skripsi, Universitas Gadjah Mada.

[9] Saad, M. S., Jamaluddin, H and mat Darus, I. Z., 2012, Implementation od PID Controller Tuning using Differential Evolution and Genetic Algorithms, International Conference on Informatics and Computing . 
[10] Patra, J., Khuntia, P. S. dan Samal, S., 2013, Analysis and Comparison of Different Performance Index factor for Conventional PID \& GA plus PID Controller, Journal of Emerging Technologies ini Computational and Applied Sciences, pp. 242-250. 